\title{
Distributive Injustice: Leadership Adherence to Social Norm Pressures and the Negative Impact on Organizational Commitment
}

\author{
LaJuan Perronoski Fuller ${ }^{1}$ \\ ${ }^{1}$ Glenn R. Jones College of Business, Trident University International, Cypress, CA, USA \\ Correspondence: LaJuan Perronoski Fuller, Ph.D., Trident University International, Cypress, CA, USA.
}

Received: June 27, 2021

Accepted: July 15, 2021

Online Published: July 30, 2021

doi:10.5539/ibr.v14n9p21

URL: https://doi.org/10.5539/ibr.v14n9p21

\begin{abstract}
The social norm theory suggests that leaders who rely on perceived norms (misperceptions) rather than actual norms may produce unfair work advantages. Furthermore, social norms alter ethical leadership behaviors. However, leadership adheres to social norms due to society's implied compliance in the absence of distributive injustice measurements. Therefore, distributive injustice may be a more salient predictor than distributive justice on affective organizational commitment. The aim of this study was to fill gaps in literature on distributive injustice and investigate negative influences on employees' affective commitment. A distributive injustice scale was designed using employee perceptions of policies that create unfair advantages and meritless rewards. The distributive injustice scale consisted of 14 items. A survey was sent to 481 full-time employees in various industries throughout the U.S. Correlation and regression model output indicated that unfair advantages and meritless rewards had a negative relationship and influence on employees' affective commitment. Social norm policies that create unfair advantages and meritless rewards can be perceived as a divisionary tacit that negatively impacts affective commitment.
\end{abstract}

Keywords: distributive injustice, organizational commitment, affective commitment, social norms

\section{Introduction}

Leadership adherence to social norms is implied and can camouflage fairness without a distributive injustice measurement (Rupp \& Spencer, 2006). The social norm theory (SNT) posits that distributive justice correlates with employees' perception of an ethical leader (Gao \& He, 2017). Additionally, SNT suggests that leaders who rely on perceived norms (misperceptions) rather than actual norms may produce unfair work advantages. Consequently, perceived norms may be observed as unfair and may negatively affect employees' work behaviors, attitudes, and commitment to the organization. Perceived norms can be problematic as pressure to conform has adversely modified ethical behavior (Pryor et al., 2019).

Pressure to conform negatively influence ethical behavior and attitudes (Dempsey et al., 2018). Nonetheless, leadership compliance is implied in the absence of suitable decision-making alternatives (Bell \& Cox, 2015; Dannals \& Miller, 2017; Siu et al., 2012). Bell and Cox (2015) used uncertainty, identity, reward, and enforcement pathways to explain how pressures of conformity influence leadership decision-making to reduce fear of sanctions, signal for acceptance, or promote a desire to harmonize (Young, 2015). However, implied compliance due to uncertainty and identity might be perceived as distributive injustice and degrade organizational commitment (OC).

Many scholars have hypothesized that distributive injustice is a salient predictor of OC and "changes the needle" on predicting employee attitudes and behaviors (Colquitt and Rodell, 2015; Cropanzano et al., 2011; Rupp \& Spencer, 2006). OC consists of continuance commitment (need to maintain employment), normative commitment (obligation to maintain employment), and affective commitment (psychological bond to the organization). Affective commitment (AC) has emerged as the most significant predictor and measure of an employee's behavior and actions (Chung \& Rimal, 2016; Zimmerman et al., 2020). Thus, it is beneficial to investigate SNT influenced policies and the possible negative predictive power of AC.

There are deficiencies in the literature on social norms that may influence distributive injustice. Furthermore, Rupp and Spencer (2006) suggest that justice may become camouflaged without reliable distributive injustice measurements. The goal of this study was to fill gaps in the literature on distributive injustice and affective 
commitment. Furthermore, it is plausible that distributive injustice may negatively affect employees' Affective commitment (Bies, 2002; Colquitt \& Rodell, 2015; Cropanzano et al., 2011; Rupp \& Spencer, 2006).

This research analyzed employee perception of unfair advantages and meritless rewards to develop a distributive injustice measurement scale. Distributive injustice was derived from measurements based on rule violations and fairness (Neville et al., 2000), employee reactions to injustice/justice (Colquitt \& Rodell, 2015), and injustice of multiculturalism/colorblindness (Henry \& Sears, 2002; Katz \& Hass, 1988). These items were revised and presented as a Perceived Employee Distributive Injustice (PEDI) scale. This scale accounts for Bell and Cox's (2015) uncertainty and identity pathways used to explain SNT's pressure to conform influence on SNT. Therefore, if employees perceive policies that create unfair advantages and meritless rewards, then these policies will have a negative relationship with affective commitment.

Research Question 1: Do employee perceptions of unfair advantages and meritless rewards based on social norm identity constitute a reliable distributive injustice measurement scale?

Research Question 2: Do policies that create unfair advantages and meritless rewards based on social norm identity negatively affect affective commitment?

\section{Literature Review}

The literature on SNT, self-categorization theory (SCT), and social identity theory (SIT) are used to better understand social norm development and ethical values. SNT was first used in 1986 by Perkins and Berkowitz, who theorized that pressures of conformity introduce misperceptions of how groups think and act. Misperceptions are based on perceived norm behavior rather than on actual norm behavior. Perceived norms are described as what one views as typical or standard in a group of people; actual norms are based on real beliefs and actions. Misperception is the gap between perceived and actual norms. As a result, group members have negative peer behaviors when perceived norms differ from actual norms (Dempsey et al., 2018). Perceived norms may also degrade employees' psychological bond with the organization.

Social norms are described as rules and standards that group members understand and that guide social behavior without the force of law (Cialdini \& Goldstein, 2004; Cialdini \& Trost, 1998). According to Chung and Rimal (2016), social norms are conceptualized in perceived normative peer behavior and attitudes as significant predictors for organizational commitment. SNT focuses on two types of (mis)conceptions: injunctive norms and descriptive norms. Injunctive relates to perceived attitudes or approval of behaviors by others; descriptive norms relate to perceptions of others' engagement in adverse behaviors (McAlaney et al., 2015). Injunctive and descriptive norms have important implications related to overestimating behaviors and attitudes based on perceived socially desirable behavior. Therefore, leaders' perceptions (injunctive) are likely grounded in misconceptions; pressures of conformity (descriptive) alter ethical viewpoints.

Most people use social norm pathways to express morals, embody values, self-understanding, and identity (Lapinski \& Rimal, 2005). In the absence of suitable norm alternatives, leaders may comply (pressures of conformity) by attempting to identify with that norm to reduce negative consequences (Bell \& Cox, 2015; Dannals \& Miller, 2017; Siu et al., 2012). Bell and Cox (2015) presented four pathways to explain the influence of social norms on people. The uncertainty pathway suggests that people look at others when unsure of the best course of action. The identity pathway suggests that people comply with social norms to express membership in a group. The reward pathway suggests that people anticipate rewards for compliance. The enforcement pathway suggests that the group forces individuals into compliance. These pathways explain how pressures of conformity lead to discriminatory practices and negative outcomes (Young, 2015).

Pressures of conformity encourage discriminatory practices (Haslam \& Stratemeyer, 2016; Neuberg \& DeScioli, 2015). The pathway approach by Bell and Cox (2015) was used to investigate leadership decision-making. Vaitla et al. (2017) confirmed pressures of conformity influenced these pathways. Leaders should consider both negative and positive consequences based on compliance or noncompliance to a norm (Chung \& Rimal, 2016; Morris et al., 2015). Leaders are more likely to focus on negative economic consequences, such as paying fines for violating norms (Morris et al., 2015; Vaitla et al., 2017) or having a negative impact on their reputation (Bell $\&$ Cox, 2015; Mackie et al., 2015).

The majority of SNT research has involved peer-to-peer cooperation and social order. Studies have shown that social norms affect health and well-being (Anderson \& Dunning, 2014; Boytsun et al., 2011; Burke \& Young, 2011; Dannals \& Miller, 2017; Young, 2015). Social norms can be harmful to decision-makers by encouraging unhealthful behaviors such as drinking alcohol and sharing needles to conform (Bell \& Cox, 2015; Dannals \& Miller, 2017). These adverse affects may likely contribute to employee perceived injustices. Therefore, 
additional research is needed to understand the pressures of conformity and distributive injustice policies.

According to Turner et al. (1987), SI is closely related to the organization, and social norms may influence distributive justice based on affective ties (psychological attachment). Perceived injustices are based on comparing social norm in-group outcomes with other collective outgroup outcomes (Kelly \& Breinlinger, 1996; Mummendey et al., 1999; Smith \& Spears, 1996). Injustices are centered on a person's perception of fairness. This study applied theoretical foundations using SNT and SIT better understand (mis)perceptions, pressures of conformity, distributive injustices.

The SI approach consists of the SI (Tajfel \& Turner, 1979) and the SCT. The SI approach suggests that behavior is influenced by intergroup relations and identification (Brown, 2020). This has been confirmed in politics (Bonneau \& Cann, 2015), management (Steffens et al., 2014), perceived workability and labor force (McGonagle et al., 2015), and education (Smyth et al., 2017). Academic communities widely accept that SI and self-categorization influence decision-making behaviors. The SI approach explains leadership attempts to identify with an identity through distributive justice policies. However, this may be more subject to perceived norms rather than to actual norms of an employee's social group's characteristics and norms.

An employee's self-perception is measured by in-group similarity, the strength of bond, and group affiliation (Farivar et al., 2018). SIT may explain distributive justice policy-making used to facilitate an employee's social affiliation by following this three-step process (Table 1).

Table 1 . Social identity theory mental process

\begin{tabular}{ll}
\hline Social Identity Theory Steps & Meaning \\
\hline Social Categorization & Leaders classify employees based on perceived norms. \\
Social Identification & $\begin{array}{l}\text { Employee strength of bond with a social group may affect affective } \\
\text { commitment. }\end{array}$ \\
Social Comparison & Leaders may compare employees to a perceived norm. \\
\hline
\end{tabular}

SI suggests collective emotions that are influenced by group actions (Yzerbyt et al., 2004). A theoretical question was proposed as to whether perceptions of affective injustice (individual) or nonaffective injustice (collective) better predict injustice (van Zomeren et al., 2008). However, people tend to rely on distributive justice on a collective approach (Cropanzano et al., 2011) and compare it with their SI to measure injustice (van Zomeren et al., 2008). Therefore, PEDI should advance our understanding of SI as a distributive injustice measurement scale.

Hao et al. (2016) and Guo et al. (2019) reported that local culture (in-group) and nonlocal culture (outgroup) influenced customer purchasing habits and buying power. Guo et al. (2019) added that local customers characterized foreign brands as outgroups based on perceived (misperceptions) of nonsimilar cultural characteristics. This is consistent with consumer-based studies by Yuan et al. (2016). Similarly, as leaders focus on SI, misperceptions about an employee's social group could degrade AC based on employee perceptions of distributive injustice.

Employees compare their value in the organization by outcomes associated with distributive justice. This concept is also known in the literature as social comparison, which builds on the equity position theory approach (Adams, 1965). Equity position theory suggests that people perceive unfairness when outcomes such as promotion opportunities, job security, and pay are less favorable (Ambrose \& Schminke, 2003; Leventhal, 1980). Based on equity position theory, employees may perceive unfairness when policies are likely to negatively impact AC. This confirmed the need to investigate the negative impact of distributive injustice on employee behaviors and attitudes (Colquitt \& Rodell, 2015).

Distributive justice is derived from the equity theory (Adams, 1965) and policies that are perceived by employees as fair influence OC (Cropanzano \& Greenberg, 1997; J. Kim et al., 2021). Policy-making is a primary element of distributive justice, and influences employee work attitudes and behaviors (Cohen-Charash \& Spector, 2001). Distributive justice is most effective when employees perceive fairness in outcome distributions (Colquitt \& Rodell, 2015; Piccoli \& Belotto, 2015). This research suggests that the injustice of multiculturalism/colorblindness scale (Katz \& Hass, 1988; Henry \& Sears, 2002) will contribute to providing an adequate measurement of SNT and SIT influenced distributive injustice.

Fair treatment of employees in the workplace significantly improves their overall attitude and behavior (Kivimäki et al., 2003). This is known as a type of distributive justice, and measures influence organizational 
legitimacy (Hudson et al., 2019) and predict AC (Hur \& Ha, 2019). Distributive justice establishes ethical policies based on fairness in resource allocation and rewards (Tatum et al., 2003). Employees perceive distributive justice as ethical, and thus it has a positive influence on employees' commitment to the organization (Colquitt \& Rodell, 2015; Hur \& Ha, 2019; Jehanzeb, 2020; Jiang \& Lavaysse, 2018; Ohana \& Meyer, 2016). Comparatively, distributive injustice is defined as unfair treatment, and meritless may harm employees' mental health (An et al., 2015) and increases stress (H. Lee et al., 2019). This is likely to have a negative relationship with AC. Therefore, this research measured employees' perception of fairness based on the scale by Neville et al. (2000).

An effective and testable distributive injustice measure is needed to determine the most salient predictor of AC (Bies, 2002; Colquitt \& Rodell, 2015; Cropanzano et al., 2011). Leadership actions, beliefs, and desires are constrained by social norms (Hedstrom \& Ylikoski, 2010), which alters ethical decision-making. In the presence of misconceptions and pressures for conformity, employees may perceive certain policies that promote unfair and meritless policies as a distributive injustice, which may have a negative impact on AC measurement of organizational commitment (OC). Employee reactions to injustice/justice by Colquitt and Rodell (2015) were used to account for employee perception. Therefore, this research considers distributive injustice as perceived norms that employees view as creating unfair advantages and meritless rewards.

OC suggests that employee behavior and attitude directly relate to the psychological bond to the organization (L. Jiang \& Lavaysse, 2018; Meyer \& Allen, 1991). Hedstrom and Swedberg (1998) suggested that social mechanisms provided an understanding of collective actions but were more meaningful in influencing interactions between individuals (Ongaro, 2019; Ongaro et al., 2021). Affective OC is the psychological tie that binds employees to the organization and mediates leadership empowerment styles (M. Kim \& Beerh, 2020). Followers' perceptions of leadership are important to measure AC. This form of OC reflects the deep and emotional relationship between the organization and the employee.

Research on employee interactions and feelings can be advanced by studying AC. AC measures the emotional attachment to, identification with, and involvement with the organization; employees who measure high in AC have intrinsic motivation and want to achieve organizational outcomes. As a result, AC has a significant influence on job satisfaction, job performance, and organizational citizenship behavior (LePine et al., 2002; Rosen et al., 2020). Leadership styles are responsible for developing employees' AC (Clinebell et al., 2013; Wiza \& Hlanganipai, 2014). Comparatively, organizational justice has a positive association with AC (Berthelsen et al., 2018). Therefore, understanding distributive injustice based on policies that produce unfair advantages and meritless rewards should help leaders recognize social norm adherence that may negatively affect employees' bond to the organization (see Figure 2).

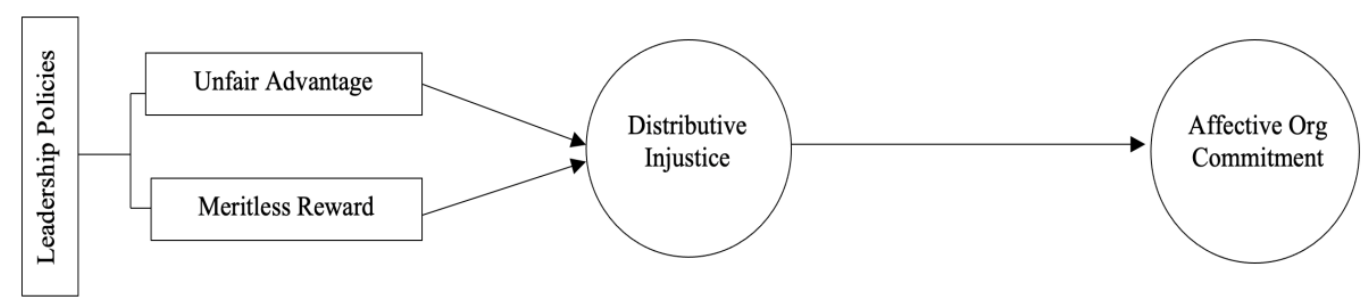

Figure 2. Distributive Injustice and Affective Commitment Conceptual Model

The social exchange theory allowed researchers to understand leadership styles and follower behaviors. Leaders who were perceived as highly professional and ethical tended to receive greater AC from employees (J. Lee \& Wei, 2017). Employees who are high in AC adopt effective knowledge-sharing practices (Camelo-Ordaz, 2011; Naeem et al., 2019). Leaders who seek to improve knowledge sharing or reduce knowledge hiding can benefit from understanding distributive injustice on AC. Additionally, employees with strong AC increase goal accomplishment and have low turnover rates (Malek et al., 2018; Santhanam et al., 2017). This implies that AC accounts for employees' emotional attachment to the organization. However, misperceptions based on perceived rather than actual norms may lead to unfair policies and meritless rewards, which may have a negative relationship with AC. This researcher proposed the following hypotheses.

$\mathrm{H}_{0}$ : Employees will perceive leadership policies that create unfair advantages and meritless rewards as a distributive injustice and has no relationship with affective commitment. 
$\mathrm{H}_{1}$ : Employees will perceive leadership policies that create unfair advantages and meritless rewards as a distributive injustice and have a negative relationship with affective commitment.

\section{Method}

This study used a cross-sectional, quantitative study design. The research followed general procedures of linear regression analysis. Pretests were not established because questions were derived from multiple sources. The 14-item PEDI scale was reverse coded, and Cronbach's alpha testing confirmed the validity and reliability of the scale. Pearson correlation was calculated to measure the overall relationship between PEDI and AC. A linear regression model was used to measure the overall influence of PEDI on AC. An analysis of variance (ANOVA) was conducted on the control variables gender and age to identify differences between these collective groups.

The participant population consisted of full-time employees based on U.S. workforce data retrieved from the U.S. Department of Labor, current as of June 2019. The U.S. workforce is estimated at approximately 156.6 million (not including seasonal or holiday employees). This study used a confidence interval (CI) of $95 \%$ with an acceptable margin of error of $4 \%$ to $6 \%$. The minimum acceptable sample size was 270 ; the aim was a minimum of 300 participants to meet correlation and regression analysis criteria. Part-time or seasonal employees or self-employed persons did not participate to streamline the process and to minimize erroneous data.

The study relied on a questionnaire for data collection. The questionnaire was derived from literature and previous measurement scales. Distributive injustice was defined as employees' perception of distributive justice policies based on creating unfair advantages and meritless rewards. The PEDI measurement derived questions from Colquitt and Rodell (2015) and Neville et al. (2000), with a focus on rule violations, fairness, and injustice of multiculturalism to capture cognitive aspects of social attitudes, as opposed to their evaluation of racial groups. Additionally, PEDI incorporated existing modern racism and colorblindness scales (e.g., Henry \& Sears, 2002; Katz \& Hass, 1988; Neville et al., 2000). PEDI consisted of 14 items to measure distributive injustice, using a 7-point Likert-type scale $(1=$ strongly disagree to $7=$ strongly agree $)$. For example, specific policies that focus solely on race/ethnicity, gender, sexual orientation, or age in the workplace are inherently unjust; it is unethical for policies to provide rewards or punishments in the workplace based simply on race/ethnicity, gender, sexual orientation, or age.

AC measures an employee's psychological bond with an organization (Tremblay et al., 2019). This research addressed only affective OC for the following reasons. First, affective and normative commitment are significantly correlated, and past research has shown a strong overlap in the determinants and consequences of the constructs (Meyer et al., 2002). However, evidence of employee psychological bond is stronger when using AC instead of other commitment measures (Bolon, 1997). In this study, AC was measured by 8 items constructed from existing scales derived from Allen and Meyer (1990) and Meyer et al. (1993), such as "I feel emotionally attached to the strategic choices of my organization" and "The values advocated by top management are aligned with my own."

In a study by Chizema and Pogrebna (2019), gender and age had no statistically significant correlation with social norm influence on leadership integrity in corporate governance. Jaswal (2019) reported that gender did not correlate with commitment and citizenship behavior. Therefore, this study used gender and age as control variables to provide insight into the investigation.

The survey was sent via SurveyMonkey ${ }^{\mathrm{TM}}$; each participant was required to read instructions before responding to the survey. Participants who selected "I do not agree" were not given access to the survey and were diverted to a screen stating, "Thank you for your participation." Participants who agreed to participate were given access to the survey after signing informed consent. Each response was given under anonymous conditions, and no personally identifiable information was collected.

The researcher collected and analyzed data from 481 participants to measure the possible negative influence of PEDI on AC. However, 41 responses were deleted due to incomplete or erroneous responses. Therefore, measures of the independent variable PEDI and dependent variable AC were based on results from 440 completed surveys from full-time employees in the United States. The survey asked respondents to indicate a level of agreement to each of 14 items based on a 7-point Likert scale $(1=$ strongly disagree to $7=$ strongly agree). IBM Statistical Program for Social Sciences (SPSS) was used for this analysis. PEDI measurement scale was reverse coded, and means and standard deviations were computed. Next, Cronbach's alpha was used to determine PEDI's 14-item and AC's 8-item scale reliability. A Pearson correlation and linear regression were performed using data provided from 440 full-time US employees. 


\section{Results}

Summary statistics were calculated for 440 participants. The most frequently observed participants were in the age group 45-60 $(n=140,32 \%)$ and female $(n=236,54 \%)$. Frequencies and percentages are presented in Table 2 .

Table 2. Participant demographics

\begin{tabular}{lcc}
\hline Variable & $n$ & $\%$ \\
\hline Age & 109 & \\
$18-29$ & 106 & 24.77 \\
$30-44$ & 140 & 24.09 \\
$45-60$ & 85 & 31.82 \\
$>60$ & & 19.32 \\
Gender & 204 & \\
Male & 236 & 46.36 \\
Female & & 53.64 \\
\hline
\end{tabular}

\subsection{Statistics and Data Analysis}

The items in the PEDI were reverse coded. Each item, including AC measurements, met acceptable skewness and kurtosis levels. (When skewness is greater than 2 in absolute value, the variable is considered to be asymmetrical about its mean; when kurtosis is greater than or equal to 3, the variable's distribution is markedly different from a normal distribution in its tendency to produce outliers; Westfall \& Henning, 2013). Table 3 presents the summary statistics.

Table 3. Summary statistics for interval and ratio variables

\begin{tabular}{lcccccccc}
\hline Variable & $M$ & $S D$ & $n$ & $\mathrm{SE}_{\mathrm{M}}$ & Min & Max & Skewness & Kurtosis \\
\hline PEDI1 & 2.43 & 1.75 & 440 & 0.08 & 1.00 & 7.00 & 1.18 & 0.37 \\
PEDI2 & 2.08 & 1.52 & 440 & 0.07 & 1.00 & 7.00 & 1.66 & 2.13 \\
PEDI3 & 2.41 & 1.75 & 440 & 0.08 & 1.00 & 7.00 & 1.25 & 0.55 \\
PEDI4 & 2.66 & 1.86 & 440 & 0.09 & 1.00 & 7.00 & 1.03 & -0.07 \\
PEDI5 & 2.51 & 1.73 & 440 & 0.08 & 1.00 & 7.00 & 1.04 & 0.05 \\
PEDI6 & 2.35 & 1.63 & 440 & 0.08 & 1.00 & 7.00 & 1.25 & 0.74 \\
PEDI7 & 3.20 & 1.91 & 440 & 0.09 & 1.00 & 7.00 & 0.53 & -0.81 \\
PEDI8 & 2.65 & 1.75 & 440 & 0.08 & 1.00 & 7.00 & 0.97 & 0.07 \\
PEDI9 & 2.90 & 1.74 & 440 & 0.08 & 1.00 & 7.00 & 0.75 & -0.34 \\
PEDI10 & 2.33 & 1.47 & 440 & 0.07 & 1.00 & 7.00 & 1.13 & 0.73 \\
PEDI11 & 2.36 & 1.66 & 440 & 0.08 & 1.00 & 7.00 & 1.25 & 0.68 \\
PEDI12 & 2.59 & 1.71 & 440 & 0.08 & 1.00 & 7.00 & 1.05 & 0.25 \\
PEDI13 & 2.56 & 1.70 & 440 & 0.08 & 1.00 & 7.00 & 1.04 & 0.17 \\
PEDI14 & 2.95 & 1.80 & 440 & 0.09 & 1.00 & 7.00 & 0.65 & -0.56 \\
AC1 & 6.00 & 1.38 & 440 & 0.07 & 1.00 & 7.00 & -1.74 & 2.84 \\
AC4 & 4.74 & 1.60 & 440 & 0.08 & 1.00 & 7.00 & -0.59 & -0.24
\end{tabular}




\begin{tabular}{lllllllll} 
AC7 & 4.69 & 1.67 & 440 & 0.08 & 1.00 & 7.00 & -0.54 & -0.35 \\
AC6 & 4.45 & 1.64 & 440 & 0.08 & 1.00 & 7.00 & -0.39 & -0.42 \\
AC3 & 4.04 & 1.77 & 440 & 0.08 & 1.00 & 7.00 & -0.22 & -0.89 \\
AC2 & 4.83 & 1.60 & 440 & 0.08 & 1.00 & 7.00 & -0.45 & -0.50 \\
AC5 & 4.86 & 1.62 & 440 & 0.08 & 1.00 & 7.00 & -0.72 & -0.09 \\
AC8 & 4.43 & 1.60 & 440 & 0.08 & 1.00 & 7.00 & -0.29 & -0.48 \\
\hline
\end{tabular}

Note PEDI $=$ Perceived Employee Distributive Injustice scale; $\mathrm{AC}=$ affective commitment.

Cronbach's alpha coefficient was evaluated using guidelines suggested by George and Mallery (2018). where $>.9=$ excellent, $>.8=$ good, $>.7=$ acceptable, $>.6=$ questionable, $>.5=$ poor, and $\leq .5=$ unacceptable. To validate the reliability of the scale, Cronbach's alpha coefficient was calculated on all 14 items, labeled PEDI1 through PEDI14. The 14 items had a Cronbach's alpha coefficient of .95, indicating excellent reliability (Table 4).

Table 4. Reliability of the Perceived Employee Distributive Injustice scale items

\begin{tabular}{llllrr}
\hline Scale & No. of Items & $\alpha$ & Lower Bound & Upper Bound \\
\hline PEDI & 14 & .95 & 0.94 & .95 \\
\hline
\end{tabular}

Note. The lower and upper bounds of Cronbach's $\alpha$ were calculated using a 95\% confidence interval.

$\mathrm{AC}$ items were labeled AC1 through AC8. The items for AC had a Cronbach's alpha coefficient of .88, indicating good reliability. Table 5 presents the results of the reliability analysis.

Table 5. Reliability Table for Affective Commitment items

\begin{tabular}{lcccc}
\hline Scale & No. of Items & $\alpha$ & $\begin{array}{c}\text { Lower } \\
\text { Bound }\end{array}$ & $\begin{array}{c}\text { Upper } \\
\text { Bound }\end{array}$ \\
\hline Affective Commitment & 8 & 0.88 & 0.87 & 0.90 \\
\hline
\end{tabular}

Note. The lower and upper bounds of Cronbach's $\alpha$ were calculated using a 95\% confidence interval.

A Pearson correlation analysis was conducted between PEDI and AC. Cohen's standard was used to evaluate the strength of the relationship, where coefficients between .10 and .29 represent a small effect size, coefficients between .30 and .49 represent a moderate effect size, and coefficients above .50 indicate a large effect size (Cohen, 1988).

A Pearson correlation requires that the relationship between the pair of variables is linear (Conover \& Iman, 1981). This assumption is violated if there is curvature among the points on the scatterplot between any pair of variables. Figure 1 presents the scatterplot of the correlation. A regression line was added to assist in interpretation.

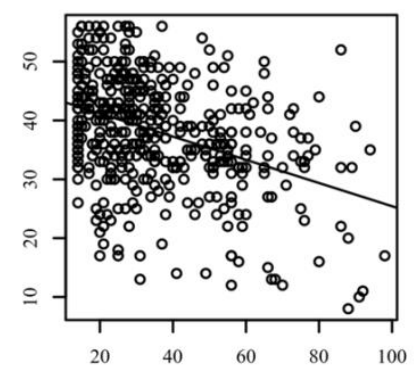

Figure 1. Scatterplot of the Correlation 
The result of the correlation was examined based on an alpha value of .05 . A significant negative correlation was observed between PEDI and AC ( $\mathrm{rp}=-0.38, p<.001,95 \%$ CI $[-0.46,-0.30])$. The correlation coefficient for PEDI and $\mathrm{AC}$ was -0.38 , indicating a moderate effect size. This correlation indicates that, as PEDI increased, AC tended to decrease (Table 6).

Table 6. Pearson correlation results between PEDI and AC $(N=440)$

\begin{tabular}{lrrr}
\hline Combination & $\mathrm{r}_{\mathrm{p}}$ & $95 \% \mathrm{CI}$ & $\mathrm{p}$ \\
\hline PEDI-AC & -0.38 & {$[-0.46,-0.30]$} & $<.001$ \\
\hline
\end{tabular}

One or more univariate outliers were detected, which may have reduced the power of the Pearson correlation. A Spearman correlation analysis was conducted to complement these results. Cohen's (1988) standard was used to evaluate the strength of the relationship. The result was examined based on an alpha value of .05 . A significant negative correlation between PEDI and AC was observed ( $\mathrm{rs}=-0.33, p<.001,95 \% \mathrm{CI}[-0.41,-0.25])$. The correlation coefficient was -0.33 , indicating a moderate effect size. This correlation indicated that, as PEDI increased, AC tended to decrease (Table 7).

Table 7. Spearman correlation results Between PEDI and AC $(N=440)$

\begin{tabular}{lrrr}
\hline Combination & $\mathrm{r}_{\mathrm{s}}$ & $95 \% \mathrm{CI}$ & $\mathrm{p}$ \\
\hline PEDI-AC & -0.33 & {$[-0.41,-0.25]$} & $<.001$ \\
\hline
\end{tabular}

Linear regression analysis was conducted to assess whether PEDI significantly predicted AC. The assumption of normality was assessed by plotting the quantiles of the model residuals against the quantiles of a Chi-square distribution, also called a Q-Q scatterplot (DeCarlo, 1997). For the assumption of normality to be met, the quantiles of the residuals must not deviate strongly from the theoretical quantiles. Strong deviations could indicate that the parameter estimates are unreliable. Figure 2 presents a Q-Q scatterplot of the model residuals.

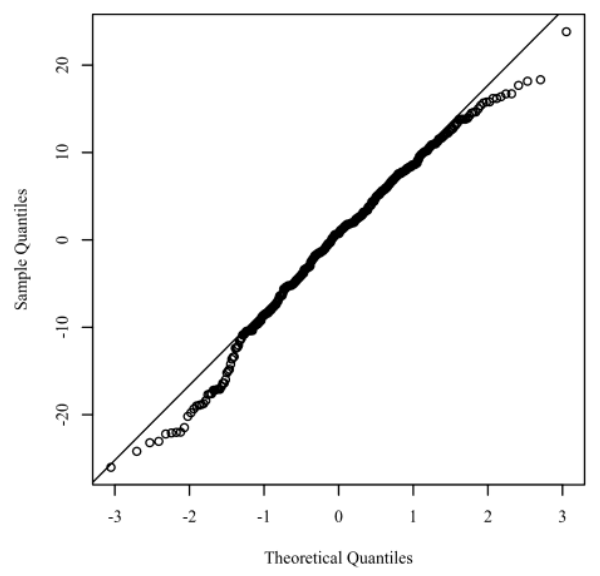

Figure 2. Q-Q scatterplot for normality of the residuals for the regression model

Homoscedasticity was evaluated by plotting the residuals against the predicted values (Bates et al., 2014; Field, 2017; Osborne \& Walters, 2002). The assumption of homoscedasticity is met if the points appear randomly distributed with a mean of zero and no apparent curvature. Figure 3 represents the plot residuals. 


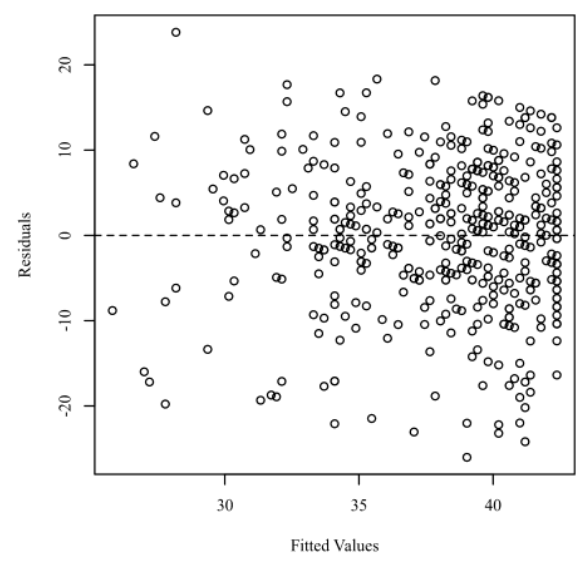

Figure 3. Residual scatterplot testing homoscedasticity

Since there was only one predictor variable, multicollinearity did not apply, and variance inflation factors were not calculated. Studentized residuals were calculated to identify influential points for outliers. Absolute values were plotted against the observation numbers (Field, 2017; Pituch \& Stevens, 2015). Studentized residuals greater than 3.11 in absolute value, the .999 quantile of a $t$ distribution with $439 d f$, was considered a significant influence on the model. No outliers detected in this dataset were detected. Figure 4 is the plot of the studentized residuals of observations.

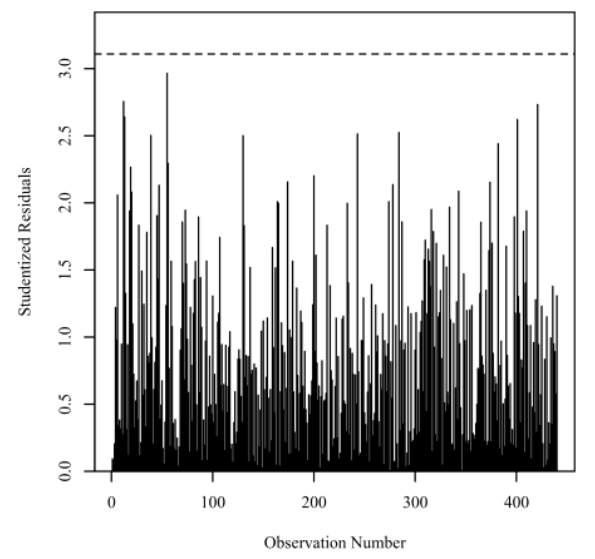

Figure 4. Studentized residuals plot for outlier detection

The results of the linear regression model were significant, $F(1,438)=74.91, p<.001, R^{2}=.15$, indicating that approximately $15 \%$ of the variance in AC was explained by PEDI. PEDI significantly predicted AC, $B=-0.20$, $t(438)=-8.66, p<.001$. This indicates that, on average, a 1 -unit increase in PEDI decreased the value of AC by 0.20 units (Table 8 ).

Table 8. Results for linear regression with PEDI predicting AC

\begin{tabular}{lrrrrrr}
\hline Variable & $\mathrm{B}$ & $\mathrm{SE}$ & $95 \% \mathrm{CI}$ & $\beta$ & $\mathrm{t}$ & $\mathrm{p}$ \\
\hline (Intercept) & 45.14 & 0.92 & {$[43.33,46.95]$} & 0.00 & 48.93 & $<.001$ \\
PEDI & -0.20 & 0.02 & {$[-0.24,-0.15]$} & -0.38 & -8.66 & $<.001$ \\
\hline
\end{tabular}

Note. Results: $F(1,438)=74.91, p<.001, R^{2}=0.15$; unstandardized regression equation: $\mathrm{AC}=45.14$ $0.20 *$ PEDI 


\subsection{Ancillary Analyses}

The ANOVA results were examined to identify differences between gender and age based on an alpha value of .05 . The results were not significant, $F(4,435)=1.88, p=.113$, indicating differences in AC by gender and age (Table 9). The results were not significant for gender, $F(1,435)=0.32, p=.571$, or Age, $F(3,435)=2.43, p$ $=.065$. Posthoc comparisons were not conducted due to these findings.

Table 9. Analysis of variance for gender and age

\begin{tabular}{lrrrrr}
\hline Term & SS & $d f$ & $F$ & $p$ & $\eta_{\mathrm{p}}{ }^{2}$ \\
\hline Gender & 29.27 & 1 & 0.32 & .571 & 0.00 \\
Age & 664.82 & 3 & 2.43 & .065 & 0.02 \\
Residuals & 39633.96 & 435 & & & \\
\hline
\end{tabular}

Means and standard deviations are presented in Table 10.

Table 10. Means, standard deviations, and sample size for ac by gender and age

\begin{tabular}{lrrr}
\hline Combination & $\mathrm{M}$ & $\mathrm{SD}$ & $\mathrm{n}$ \\
\hline Male: $18-29$ & 35.71 & 9.44 & 48 \\
Female: $18-29$ & 36.13 & 10.16 & 61 \\
Male: $30-44$ & 38.77 & 11.58 & 52 \\
Female: $30-44$ & 38.59 & 8.73 & 54 \\
Male: $45-60$ & 37.00 & 10.43 & 61 \\
Female: $45-60$ & 39.71 & 8.22 & 79 \\
Male: $>60$ & 40.14 & 9.43 & 43 \\
Female: $>60$ & 38.10 & 7.87 & 42 \\
\hline
\end{tabular}

Posthoc comparisons were not conducted because there were no significant effects in the model.

\section{Discussion}

This study advances our understanding of distributive injustice using the SI approach (Tajfel \& Turner, 1979). The SI approach helps explain how employees perceived policies that create unfair advantages, and meritless rewards lead to distributive injustices. This confirmed that leadership decision-making behaviors influence intergroup organizational relations and identification (Brown, 2020). Furthermore, an employee's self-perception is measured by in-group similarity, the strength of bond, and group affiliation (Farivar et al., 2018). Pearson correlation confirmed that unfair advantages and meritless rewards weakened the strength of bond and affiliation to the organization.

Colquitt and Rodell (2015) and Marescaux et al. (2019) suggested that distributive injustice negatively impacts employee behaviors. The linear regression output confirmed this by revealing a significant negative influence between PEDI and AC. However, more research should be done to determine the affect of unfair advantages and meritless rewards on a leader's power to motivate (Rousseau, 2005; Rousseau et al., 2006).

Leaders comply with social norms due to a lack of alternatives (Bell \& Cox, 2015; Dannals \& Miller, 2017; Siu et al., 2012) and fear of sanctions (Young, 2015). PEDI was used to account for those pressures to adhere to social norms. Leaders can use PEDI to identify policies that may negatively impact employees and better recognize discriminatory injustices (Haslam \& Stratemeyer, 2016; Neuberg \& DeScioli, 2015).

Many scholars have argued that injustice changes the needle on understanding employee attitudes and remains largely untested (Cropanzano et al., 2011). This study fills the gap in the literature and provides a process to identify distributive injustice. Nonetheless, distributive justice significantly predicts AC (Hur \& Ha, 2019; Jehanzeb, 2020; Ohana \& Meyer, 2016). However, distributive injustice has a negative association with AC. 
Therefore, leaders should consider using both measurements to improve employees' phycological bond to the organization.

This research used Bell and Cox's (2015) uncertainty pathway and identity pathway to better explain distributive injustice on affective commitment. This suggests that uncertainty and identity pathways can cause misperceptions and pressures of conformity. Leaders who desire to help will be likely to perform actions based on uncertainty to accommodate an employee's social group identity. PEDI can complement this pathway by confirming injustices among outgroup social identity members.

There was a need to help leaders recognize possible discriminatory practices caused by social norms (Haslam \& Stratemeyer, 2016; Neuberg \& DeScioli, 2015; Young, 2015). Conversely, leaders can use PEDI to ensure compliance with a social norm that will not degrade AC through discriminatory practices associated with the SNT. Ultimately, direct coercion instills uncertainty, and leaders adhere to pressures of conformity to avoid negative rewards or punishment. PEDI Cronbach's alpha measured at .95 , indicating an excellent distributive injustice measurement to balance coercion tactics and provide suitable alternatives for leadership decision-making (Dannals \& Miller, 2017).

Asj' ari et al. (2020) confirmed that people assess fairness by the divisions that it creates. PEDI advances Asj'ari et al. (2020) research by establishing unfair advantages and meritless rewards as distributive injustice and confirmed divisionary tactics had a negative impact on AC. The predictive power of PEDI on AC was consistent with previous research that employees are likely to associate injustices by rules that promote identity rather than work performance (Astuti \& Ingsih, 2019).

Leaders should use the PEDI as a suitable alternative to ensure that pressures of conformity and adherence to social norms are not unfair or meritless toward a particular employee's social group. This is consistent with Qu et al. (2013), who reported that perceptions of injustice were salient when distributive inequality was created only for those who fit a particular group. A person's identity influences how they feel about themselves and others (Tajfel \& Turner, 1979; Wang et al., 2017). This study concludes that distribution based on a particular group of employees degrades overall AC. Therefore, distributive justice leaders can use PEDI to better understand how pressures of conformity play a role in resource allocation and distribution ( $\mathrm{Lu} \&$ McKeown, 2018) and reduce employee biases as a result of perceived distributive injustices (Liu et al., 2018).

This research has limitations based on using a cross-sectional study method. Relationships between PEDI and AC may change over time. The 440 participants in this study might have yielded different ANOVA results if race or sexual orientation had been used as controls. Additionally, research teams may find it difficult to measure which is the more salient predictor between distributive justice and injustice. Therefore, researchers may have to conduct two separate tests to identify the most salient predictor.

There are possible sample biases in this investigation. First, the researcher could not measure the entire population. However, data were collected from a subset of 440 full-time employees to reduce this bias. Additionally, permission letters were sent through SurveyMonkey. Participants may have rushed or may not have fully answered each question to the best of their knowledge. To mitigate this possibility, the survey contained only 23 one-sentence items to address all variables and demographics in the study. Each item was derived from previously validated and accepted studies to decrease survey item bias.

AC has been shown to mediate leadership empowerment styles (M. Kim \& Beerh, 2020). Therefore, further research should be conducted to determine whether leadership styles mediate or moderate the negative relationship between PEDI and AC. Further studies on leadership styles may improve the literature on distributive injustice and employees' psychological bond to the organization. Learning about the relationship between leadership style and PEDI could inform leaders and managers on additional alternatives that may influence negative AC.

Gender and age were examined, and the results showed no significant effect. Future research should include other demographic categories to examine possible influences on PEDI and AC. This would inform leaders and managers about the influence of misconceptions and pressure of conformity on AC. Because distributive justice is based on peer-to-peer normative behavior, further research should study and validate the PEDI on both normative and continuance organizational commitment. This research filled the gap in the literature by providing a distributive injustice scale.

\section{Conclusion}

Distributive justice is based on the idea that resources allocation is fair and according to merit (Hudson et al., 2019). Comparatively, particularism proposed that lack of fairness is primarily due to preferential treatment 
based on a social tie rather than merit (Arasli \& Tumer 2008; Keles et al., 2011; Spranger et al., 2012). Therefore, PEDI was developed to balance current literature by measuring employee perception of unfairness and meritless rewards. As a result, PEDI confirmed that employees perceived policies that create unfair advantages and meritless rewards as injustice and significantly weakened their psychological bond to the organization. Leaders and managers can use PEDI to ensure policies are not divisionary and perceived as an injustice by employees. This will ensure that fairness does not become inconspicuous or camouflaged due to deficiencies in the literature on distributive injustice measurements (Rupp \& Spencer, 2006).

\section{References}

Adams, S. J. (1965). Inequity in social exchange. In L. Berkowitz (Ed.), Advances in experimental social psychology (Vol. 2, pp. 267-299). Academic Press. https://doi.org/10.1016/S0065-2601(08)60108-2

Allen, N. J., \& Meyer, J. P. (1990). The measurement and antecedents of affective, continuance, and normative commitment to the organization. Journal of Occupational Psychology, 63(1), 1-18. https://doi.org/10.1111/j.2044-8325.1990.tb00506.x

Ambrose, M. L., \& Schminke, M. (2003). Organization structure as a moderator of the relationship between procedural justice, interactional justice, perceived organizational support, and supervisory trust. Journal of Applied Psychology, 88(2), 295-305. https://doi.org/10.1037/0021-9010.88.2.295

An, S. J., Chung, Y. K., Kim, B. H., Kwak, K. M., Son, J. S., \& Koo, J. W. (2015). The effect of organisational system on self-rated depression in a panel of male municipal firefighters. Annals of Occupational Environmental Medicine, 27(1), 1-15. https://doi.org/10.1186/s40557-014-0044-x

Anderson, J. E., \& Dunning, D. (2014). Behavioral norms: Variants and their identification. Social and Personality Psychology Compass, 8(12), 721-738. https://doi.org/10.1111/spc3.12146

Arasli, H., \& Tumer, M. (2008). Nepotism, favoritism, and cronyism: A study of their effects on job stress and job satisfaction in the banking industry of North Cyprus. Social Behavior and Personality, 36, 1237-1250. https://doi.org/10.2224/sbp.2008.36.9.1237

Asj'ari, F., Utomo, S. P., \& Suharyanto. (2020). Procedural justice and distributive justice: Employees' organizational commitments in creative industry. Russian Journal of Agricultural and Socio-Economic Sciences, 97(1), 142-149. https://doi.org/10.18551/rjoas.2020-01.18

Astuti, S. D., \& Ingsih, K. (2019). Distributive justice improves job satisfaction and procedural justice increases organizational commitment. Calitatea, 20(169), 93-98.

Bates, D., Mächler, M., Bolker, B., \& Walker, S. (2014). Fitting linear mixed-effects models using LME4. Journal of Statistical Software. https://doi.org/10.18637/jss.v067.io1

Bell, D. C., \& Cox, M. L. (2015). Social norms: Do we love norms too much? Journal of Family Theory \& Review, 7, 28-46. https://doi.org/10.1111/jftr.12059

Berthelsen, H., Conway, P. M., Clausen, T., Malmö University, Centre for Work Life and Evaluation Studies (CTA), \& Faculty of Odontology. (2018). Is organizational justice climate at the workplace associated with individual-level quality of care and organizational affective commitment? A multi-level, cross-sectional study on dentistry in Sweden. International Archives of Occupational and Environmental Health, 91(2), 237-245. https://doi.org/10.1007/s00420-017-1275-2

Bies, R. J. (2002). Interactional (in)justice: The sacred and the profane. In J. Greenberg \& R. Cropanzano (Eds.), Advances in organizational justice (pp. 89-118). Stanford University Press.

Bolon, D. S. (1997). Organizational citizenship behaviour among hospital employees: A multidimensional analysis involving job satisfaction and organizational commitment. Hospital and Health Services Administration, 42, 221-241. https://pubmed.ncbi.nlm.nih.gov/10167456/

Bonneau, C., \& Cann, D. (2015). Party identification and vote choice in partisan and nonpartisan elections. Political Behavior, 37(1), 43-66. https://doi.org/10.1007/s11109-013-9260-2

Boytsun, A., Deloof, M., \& Matthyssens, P. (2011). Social norms, social cohesion, and corporate governance. Corporate Governance: An International Review, 19, 41-60. https://doi.org/10.1111/j.1467-8683.2010.00829.x

Bradford, B. (2014). Policing and social identity: Procedural justice, inclusion and cooperation between police and public. Policing and Society, 24(1), 22-43. https://doi.org/10.1080/10439463.2012.724068

Brown, R. (2020). The social identity approach: Appraising the Tajfellian legacy. British Journal of Social 
Psychology, 59(1), 5-25. https://doi.org/10.1111/bjso.12349

Burke, M. A., \& Young, P. H. (2011). Social norms. In J. Benhabib, A. Bisin, \& M. O. Jackson (Eds.), Handbook of social economics (Vol. 1, pp. 311-338). North-Holland.

https://doi.org/10.1016/B978-0-444-53187-2.00008-5

Camelo-Ordaz, C., Garcia-Cruz, J., Sousa-Ginel, E., \& Valle-Cabrera, R. (2011). The influence of human resource management on knowledge sharing and innovation in Spain: The mediating role of affective commitment. The International Journal of Human Resource Management, 22(7), 1442-1463. https://doi.org/10.1080/09585192.2011.561960

Chizema, A., \& Pogrebna, G. (2019). The impact of government integrity and culture on corporate leadership practices: Evidence from the field and the laboratory. Leadership Quarterly, 30(5), 101303. https://doi.org/10.1016/j.leaqua.2019.07.001

Chung, A., \& Rimal, R. N. (2016). Social norms: A review. Review of Communication Research, 4, 1-28. Retrieved from https://www.rcommunicationr.org/index.php/rcr/article/view/18

Cialdini, R. B., \& Goldstein, N. J. (2004). Social influence: Compliance and conformity. Annual Review of Psychology, 55,591-621. https://doi.org/10.1146/annurev.psych.55.090902.142015

Cialdini, R. B., \& Trost, M. R. (1998). Social influence: Social norms, conformity and compliance. In D. T. Gilbert, S. T. Fiske, \& G. Lindzey (Eds.), The handbook of social psychology (pp. 151-192). McGraw-Hill.

Clinebell, S., Skudiene, V., Trijonyte, R., \& Reardon, J. (2013). Impact of leadership style on employee organizational commitment. Journal of Service Science, 6(1), 139-152. https://doi.org/10.19030/jss.v6i1.8244

Cohen, J. (1988). Statistical power analysis for the behavior sciences (2nd ed.). West.

Cohen-Charash, Y., \& Spector, P. E. (2001). The role of justice in organizations: A meta-analysis. Organizational Behavior and Human Decision Processes, 86(2), 278-321. https://doi.org/10.1006/obhd.2001.2958

Colquitt, J. A., \& Rodell, J. B. (2015). Measuring justice and fairness. In R. S. Cropanzano \& M. L. Ambrose (Eds.), The Oxford handbook of justice in the workplace (pp. 187-202). Oxford University Press.

Colquitt, J. A., Lepine, J., \& Wesson M. (2015). Organizational behavior: Improving performance and commitment in the workplace (4th ed.). McGraw-Hill Education.

Colquitt, J. A., Long, D. M., Rodell, J. B., \& Halvorsen-Ganepola, M. D. K. (2015). Adding the "in" to justice: A qualitative and quantitative investigation of the differential effects of justice and injustice. Journal of Applied Psychology, 100, 278-297. https://doi.org/10.1037/a0038131

Conover, W. J., \& Iman, R. L. (1981). Rank transformations as a bridge between parametric and nonparametric statistics. The American Statistician, 35(3), 124-129. https://doi.org/10.1080/00031305.1981.10479327

Cropanzano, R., \& Greenberg, J. (1997). Progress in organizational justice: Tunnelling through the maze. In C. L. Cooper \& I. T. Robertson (Eds.), International review of industrial and organizational psychology (Vol. 12, pp. 317-372).Wiley.

Cropanzano, R., Stein, J. H., \& Nadisic, T. (2011). Social justice and the experience of human emotion. Taylor and Francis. https://doi.org/10.4324/9780203840474

Dannals, J. E., \& Miller, D. T. (2017). Social norms in organizations. In M. A. Hitt (Ed.), Oxford research encyclopedia of business and management. https://doi.org/10.1093/acrefore/9780190224851.013.139

DeCarlo, L. T. (1997). On the meaning and use of kurtosis. Psychological Methods, 2(3), 292-307. https://doi.org/10.1037/1082-989X.2.3.292

Dempsey, R. C., McAlaney, J., \& Bewick, B. M. (2018). A critical appraisal of the social norms approach as an interventional strategy for health-related behavior and attitude change. Frontiers in Psychology, 9, Art. 2180. https://doi.org/10.3389/fpsyg.2018.02180

Farivar, S., Turel, O., \& Yuan, Y. (2018). Skewing users' rational risk considerations in social commerce: An empirical examination of the role of social identification. Information \& Management, 55(8), 1038-1048. https://doi.org/10.1016/j.im.2018.05.008

Field, A. (2017). Discovering statistics using IBM SPSS statistics: North American edition. Sage.

Gao, Y., \& He, W. (2017), Corporate social responsibility and employee organizational citizenship behavior: The pivotal roles of ethical leadership and organizational justice. Management Decision, 55(2), 294-309. 
https://doi.org/10.1108/MD-05-2016-0284

George, D., \& Mallery, P. (2018). IBM SPSS Statistics 25 step by step. Routledge. https://doi.org/10.4324/9781351033909

Guo, X., Heinberg, M., \& Zou, S. (2019). Enhancing consumer attitude toward culturally mixed symbolic products from foreign global brands in an emerging-market setting: The role of cultural respect. Journal of International Marketing, 27(3), 79-97. https://doi.org/10.1177/1069031X19843912

Hao, J., Li, D., Peng, L., Peng, S., \& Torelli, C. J. (2016). Advancing our understanding of culture mixing. Journal of Cross-Cultural Psychology, 47(10), 1257-1267. https://doi.org/10.1177/0022022116670514

Haslam, N., \& Stratemeyer, M. (2016). Recent research on dehumanization. Current Opinion in Psychology, 11, 25-29. https://doi.org/10.1016/j.copsyc.2016.03.009

Hedstrom, P., \& Swedberg, R. (1998). Social mechanisms: An analytical approach to social theory. Cambridge University Press. https://doi.org/10.1017/CBO9780511663901

Hedstrom, P., \& Ylikoski, P. (2010). Causal mechanisms in the social sciences. Annual Review of Sociology, 36, 49-67. https://doi.org/10.1146/annurev.soc.012809.102632

Henry, P., \& Sears, D. (2002). The Symbolic Racism 2000 Scale. Political Psychology, 23, 253-283. https://doi.org/10.1111/0162-895X.00281

Hudson, S., González-Gómez, H. V., \& Claasen, C. (2019). Legitimacy, particularism and employee commitment and justice. Journal of Business Ethics, 157(3), 589-603. https://doi.org/10.1007/s10551-017-3685-1

Hur, H., \& Ha, H. (2019). The link between perceptions of fairness, job training opportunity and at-will employees' work attitudes: Lessons from U.S. Georgia state government. European Journal of Training and Development, 43, 375-397. https://doi.org/10.1108/EJTD-09-2018-0090

Jaswal, P. (2019). Relationship between organizational citizenship behavior and organizational commitment. Research Review International Journal of Multidisciplinary, 4(5), 7.

Jehanzeb, K. (2020). Does perceived organizational support and employee development influence organizational citizenship behavior? Person-organization fit as moderator European Journal of Training and Development, 44(6/7), 637-657. https://doi.org/10.1108/EJTD-02-2020-0032

Jiang, L., \& Lavaysse, L. M. (2018). Cognitive and affective job insecurity: A meta-analysis and a primary study. Journal of Management, 44(6), 2307-2342. https://doi.org/10.1177/0149206318773853

Jiang, S., Lambert, E. G., Jin, X., Xiang, D., Shi, M., \& Zhang, D. (2018). Correlates of organizational commitment among community correctional officers in China. The Prison Journal, 98(1), 60-82. https://doi.org/10.1177/0032885517743706

Katz, I., \& Hass, R. G. (1988). Racial ambivalence and American value conflict: Correlational and priming studies of dual cognitive structures. Journal of Personality and Social Psychology, 55, 893-905. https://doi.org/10.1037/0022-3514.55.6.893

Keles, H. N., Ozkan, T. K., \& Bezirci, M. (2011). A study on the effects of nepotism, favoritism and cronyism on organizational trust in the auditing process in family businesses in Turkey. International Business \& Economics Research Journal, 10(9), 9-16. https://doi.org/10.19030/iber.v10i9.5622

Kelly, C., \& Breinlinger, S. (1996). The social psychology of collective action: Identity, injustice and gender. Taylor \& Francis.

Kim, J., Milliman, J., \& Lucas, A. (2021). Effects of CSR on affective organizational commitment via organizational justice and organization-based self-esteem. International Journal of Hospitality Management, 92, 1-8. https://doi.org/10.1016/j.ijhm.2020.102691

Kim, M., \& Beehr, T. A. (2020). Empowering leadership: Leading people to be present through affective organizational commitment? International Journal of Human Resource Management, 31(16), 2017-2044. https://doi.org/10.1080/09585192.2018.1424017

Kivimäki, M., Elovainio, M., Vahtera, J., Virtanen, M., \& Stansfeld, S. A. (2003). Association between organizational inequity and incidence of psychiatric disorders in female employees. Psychology and Medicine, 33(2), 319-326. https://doi.org/10.1017/S0033291702006591

Lapinski, M. K., \& Rimal, R. N. (2005). An explication of social norms. Communication Theory, 15, 127-147. 
https://doi.org/10.1111/j.1468-2885.2005.tb00329.x

Lee, H., Um, K., Ju, Y., Lee, S., Choi, M., Paek, D., \& Cho, S. (2019). Association between organizational justice and depressive symptoms among securities company workers. Annals of Occupational and Environmental Medicine, 31(1), e7-e7. https://doi.org/10.35371/aoem.2019.31.e7

Lee, J., \& Wei, F. (2017). The moderating effect of leadership on perceived organizational justice and affective commitment: A study in China. International Journal of Human Resource Management, 28(5), 679-702. https://doi.org/10.1080/09585192.2015.1109533

LePine, J. A., Erez, A., \& Johnson, D. E. (2002). The nature and dimensionality of organizational citizen behavior: A critical review and meta-analysis. Journal of Applied Psychology, 87(1), 52-65. https://doi.org/10.1037/0021-9010.87.1.52

Leventhal, G. S. (1980). What should be done with equity theory? In K. J. Gergen, M. S. Greenberg, \& R. H. Willis, R. H. (Eds.), Social exchange: Advances in theory and research (pp. 27-55). Plenum Press. https://doi.org/10.1007/978-1-4613-3087-5_2

Liu, Y., Bian, X., Hu, Y., Chen, Y., Li, X., \& Di Fabrizio, B. (2018). Intergroup bias influences third - party punishment and compensation: In-group relationships attenuate altruistic punishment. Social Behavior and Personality: An International Journal, 46(8), 1397-1408. https://doi.org/10.2224/sbp.7193

Lu, T., \& McKeown, S. (2018). The effects of empathy, perceived injustice and group identity on altruistic preferences: Towards compensation or punishment. Journal of Applied Social Psychology, 48(12), 683-691. https://doi.org/10.1111/jasp.12558

Mackie, G., Moneti, F., Shakya, H., \& Denny, E. (2015). What are social norms? How are they measured? UNICEF.

Mahmoud, M. A., Ahmad, M. S., Yusoff, M. Z. M., \& Mustapha, A. (2014). A review of norms and normative multiagent systems. Scientific World Journal, Art. 684587. https://doi.org/10.1155/2014/684587

Malek, K., Kline, S. F., \& DiPietro, R. (2018). The impact of manager training on employee turnover intentions. Journal of Hospitality and Tourism Insights, I(3), 203-219. https://doi.org/10.1108/JHTI-02-2018-0010

Marescaux, E., De Winne, S., \& Sels, L. (2019). Idiosyncratic deals from a distributive justice perspective: Examining co-workers' voice behavior. Journal of Business Ethics, 154(1), 263-281. https://doi.org/10.1007/s10551-016-3400-7

McAlaney, J., Helmer, S., Stock, C., Vriesacker, B., Van Hal, G., Dempsey, R., ... Mikolajczyk, R. (2015). Personal and perceived peer use of and attitudes toward alcohol among university and college students in seven EU countries: Project SNIPE. Journal of Studies on Alcohol and Drugs, 76, 430-438. https://doi.org/10.15288/jsad.2015.76.430

McGonagle, A. K., Fisher, G. G., Barnes-Farrell, J. L., \& Grosch, J. W. (2015). Individual and work factors related to perceived work ability and labor force outcomes. Journal of Applied Psychology, 100(2), 376-398. https://doi.org/10.1037/a0037974

Meyer, J. P., \& Allen, N. (1991). A three-component conceptualization of organizational commitment. Human Resource Management Review, 1, 61-89. https://doi.org/10.1016/1053-4822(91)90011-Z

Meyer, J. P., Allen, N. J., \& Smith, C. A. (1993). Commitment to organizations and occupations: Extension and test of a three-component conceptualization. Journal of Applied Psychology, 78(4), 538-551. https://doi.org/10.1037/0021-9010.78.4.538

Meyer, J. P., Stanley, D. J., Herscovitch, L., \& Topolnytsky, L. (2002). Affective, continuance, and normative commitment to organization: A meta-analysis of antecedents, correlates, and consequences. Journal of Vocational Behavior, 61, 20-52. https://doi.org/10.1006/jvbe.2001.1842

Michel, J., \& Hargis, M. (2016). What motivates deviant behavior in the workplace? An examination of the mechanisms by which procedural injustice affects deviance. Motivation and Emotion, 41(1), 51-68. https://doi.org/10.1007/s11031 - $016-9584-4$

Morris, M. W., Hong, Y. Y., Chiu, C. Y., \& Liu, Z. (2015). Normology: Integrating insights about social norms to understand cultural dynamics. Organizational Behavior and Human Decision Processes, 129, 1-13. https://doi.org/10.1016/j.obhdp.2015.03.001

Mummendey, A., Kessler, T., Klink, A., \& Mielke, R. (1999). Strategies to cope with negative social identity: Predictions by social identity theory and relative deprivation theory. Journal of Personality and Social 
Psychology, 76, 229-245. https://doi.org/10.1037/0022-3514.76.2.229

Naeem, A., Mirza, N., Ayyub, R., \& Lodhi, R. (2019). HRM practices and faculty's knowledge-sharing behavior: Mediation of affective commitment and affect-based trust. Studies in Higher Education, 44(3), 499-512. https://doi.org/10.1080/03075079.2017.1378635

Neuberg, S. L., \& DeScioli, P. (2015). Prejudices: Managing perceived threats to group life. In D. M. Buss (Ed.), The handbook of evolutionary psychology (pp. 669-683). Wiley. https://doi.org/10.1002/9781119125563.evpsych228

Neville, H. A., Lilly, R. L., Duran, G., Lee, R. M., \& Browne, L. (2000). Construction and initial validation of the Color-Blind Racial Attitudes Scale (CoBRAS). Journal of Counseling Psychology, 47, 59-70. https://doi.org/10.1037/0022-0167.47.1.59

Ohana, M., \& Meyer, M. (2016). Distributive justice and affective commitment in nonprofit organizations: Which referent matters? Employee Relations, 38(6), 841-858. https://doi.org/10.1108/ER-10-2015-0197

Ongaro, E. (2019). The teaching of philosophy in public administration programmes. Teaching Public Administration, 37(2), 135-146. https://doi.org/10.1177/0144739419837310

Ongaro, E., Gong, T., \& Jing, Y. (2021). Public administration, context and innovation: A framework of analysis. Public Administration and Development, 4l(1), 4-11. https://doi.org/10.1002/pad.1902

Osborne, J., \& Waters, E. (2002). Four assumptions of multiple regression that researchers should always test. Practical Assessment, Research \& Evaluation, 8(2), 1-9. Retrieved from https://scholarworks.umass.edu/cgi/viewcontent.cgi?article=1111\&context=pare

Pelletier, K., \& Bligh, M. (2008). The aftermath of organizational corruption: Employee attributions and emotional reactions. Journal of Business Ethics, 80(4), 823-844. https://doi.org/10.1007/s10551-007-9471-8

Piccoli, B., \& Belotto, M. (2015). New insights for the management of job insecurity-psychological well-being relationship. Journal of Economics, Business, and Management, 3(11), 1080-1086. https://doi.org/10.7763/JOEBM.2015.V3.338

Pituch, K. A., \& Stevens, J. P. (2015). Applied multivariate statistics for the social sciences (6th ed.). Routledge Academic. https://doi.org/10.4324/9781315814919

Pryor, C., Perfors, A., \& Howe, P. D. L. (2019). Even arbitrary norms influence moral decision-making. Nature of Human Behavior, 3, 57-62. https://doi.org/10.1038/s41562-018-0489-y

Qu, C., Wang, Y., \& Huang, Y. (2013). Social exclusion modulates fairness consideration in the ultimatum game: An ERP study. Frontiers in Human Neuroscience, 7, 505-511. https://doi.org/10.3389/fnhum.2013.00505

Rosen, C. C., Dimotakis, N., Cole, M. S., Taylor, S. G., Simon, L. S., Smith, T. A., \& Reina, C. S. (2020). When challenges hinder: An investigation of when and how challenge stressors impact employee outcomes. Journal of Applied Psychology, 105(10), 1181-1206. https://doi.org/10.1037/ap10000483

Rousseau, D. M. (2005). I-deals: Idiosyncratic deals employees bargain for themselves. M. E. Sharpe.

Rousseau, D. M., Ho, V. T., \& Greenberg, J. (2006). I-deals: Idiosyncratic terms in employment relationships. Academy of Management Review, 31(4), 977-994. https://doi.org/10.5465/amr.2006.22527470

Rupp, D. E., \& Spencer, S. (2006). When customers lash out: The effects of customer interactional injustice on emotional labor and the mediating role of discrete emotions. Journal of Applied Psychology, 91(4), 971-978. https://doi.org/10.1037/0021-9010.91.4.971

Rusbult, C. E., Farrell, D., Rogers, G., \& Mainous, A. G. (1988). Impact of exchange variables on exit, voice, loyalty and neglect: An integrative model of responses to declining job satisfaction. Academy of Management Journal, 31(3), 599-627. https://doi.org/10.2307/256461

Santhanam, N., Kamalanabhan, T. J., Dyaram, L., \& Ziegler, H. (2017). Impact of human resource management practices on employee turnover intentions: Moderating role of psychological contract breach. Journal of Indian Business Research, 9(3), 212-228. https://doi.org/10.1108/JIBR-10-2016-0116

Siu, A. M. H., Shek, D. T. L., \& Law, B. (2012). Prosocial norms as a positive youth development construct: A conceptual review. Scientific World Journal, Art. 832026. https://doi.org/10.1100/2012/832026

Smith, H. J., \& Spears, R. (1996). Ability and outcome evaluations as a function of personal and collective (dis)advantage: A group escape from individual bias. Personality and Social Psychology Bulletin, 22(7), 690-704. https://doi.org/10.1177/0146167296227004 
Smyth, L., Mavor, K. I., \& Platow, M. J. (2017). Learning behaviour and learning outcomes: The roles for social influence and field of study. Social Psychology Education, 20, 69-95. https://doi.org/10.1007/s11218-016-9365-7

Spranger, J. L., Colarelli, S. M., Dimotakis, N., Jacob, A. C., \& Arvey, R. D. (2012). Effects of kin density within family-owned businesses. Organizational Behavior and Human Decision Processes, 119(2), 151-162. https://doi.org/10.1016/j.obhdp.2012.07.001

Steffens, N. K., Haslam, S. A., Reicher, S. D., Platow, M. J., Fransen, K., Yang, J., ... Boen, F. (2014). Leadership as social identity management: Introducing the Identity Leadership Inventory (ILI) to assess and validate a four-dimensional model. Leadership Quarterly, 25(5), 1001-1024. https://doi.org/10.1016/j.leaqua.2014.05.002

Tajfel, H., \& Turner, J. C. (1979). An integrative theory of inter-group conflict. In W. G. Austin \& S. Worchel (Eds.), The social psychology of inter-group relations (pp. 33-47). Brooks/Cole.

Tatum, B., Eberlin, R., Kottraba, C., \& Bradberry, T. (2003). Leadership, decision making, and organizational justice. Management Decision, 41, 1006-1016. https://doi.org/10.1108/00251740310509535

Tremblay, M., Gaudet, M. C., \& Vandenberghe, C. (2019). The role of group-level perceived organizational support and collective affective commitment in the relationship between leaders' directive and supportive behaviors and group-level helping behaviors. Personnel Review, 48(2), 417-437. https://doi.org/10.1108/PR-06-2017-0172

Turner, J. C., Hogg, M. A., Oakes, P. J., Reicher, S. D., \& Wetherell, M. S. (1987). Rediscovering the social group: A self-categorization theory. Basil Blackwell.

Vaitla, B., Taylor, A., Van Horn, J., \& Cislaghi, B. (2017). Social norms and girls'well-being: Linking theory and practice. Data2X.

van Zomeren, M., Postmes, T., \& Spears, R. (2008). Toward an integrative social identity model of collective action: A quantitative research synthesis of three socio-psychological perspectives. Psychological Bulletin, 134(4), 504-511. https://doi.org/10.1037/0033-2909.134.4.504

Wang, Y., Zhang, Z., Bai, L., Lin, C., Osinsky, R., \& Hewig, J. (2017). In-group/outgroup membership modulates fairness consideration: Neural signatures from ERPs and EEG oscillations. Scientific Reports, 7, Art. 39827. https://doi.org/10.1038/srep39827

Westfall, P. H., \& Henning, K. S. S. (2013). Texts in statistical science: Understanding advanced statistical methods. Taylor \& Francis. https://doi.org/10.1201/b14398

Wiza, M., \& Hlanganipai, N. (2014). The impact of leadership styles on employee organisational commitment in higher learning institutions. Mediterranean Journal of Social Sciences, 5(4), 135-143. https://doi.org/10.5901/mjss.2014.v5n4p135

Young, P. (2015). The evolution of social norms. Annual Review of Economics, 7, 359-387. https://doi.org/10.1146/annurev-economics-080614-115322

Yuan, D., Cui, G., \& Lai, L. (2016). Sorry seems to be the hardest word: Consumer reactions to self-attributions by firms apologizing for a brand crisis. Journal of Consumer Marketing, 33(4), 281-291. https://doi.org/10.1108/JCM-02-2015-1306

Yzerbyt, V., Dumont, M., Wigboldus, D., \& Gordijn, E. (2004). I feel for us: The impact of categorization and identification on emotions and action tendencies. British Journal of Social Psychology, 42, 533-549. https://doi.org/10.1348/014466603322595266

Zimmerman, A., Lioliou, E., \& Oliveira, J. (2020). How do offshoring-related changes in job characteristics affect onshore managers' affective organizational commitment? The moderating role of perceived organizational valence. Journal of Information Technology, 35(4), 316-336.

https://doi.org/10.1177/0268396220942237

\section{Copyrights}

Copyright for this article is retained by the author(s), with first publication rights granted to the journal.

This is an open-access article distributed under the terms and conditions of the Creative Commons Attribution license (http://creativecommons.org/licenses/by/4.0/). 